\title{
Race and faith: the Catholic Church, clerical Fascism, and the shaping of Italian anti-semitism and racism
}

\author{
Nina Valbousquet* \\ Center for Jewish History and Skirball Department of Hebrew and Judaic studies, New York University, \\ USA
}

(Received 21 January 2018; final version accepted 28 July 2018)

\begin{abstract}
In this essay, I argue that despite the Vatican's condemnation of Nazi racism as an antiChristian ideology, some Catholic sectors in Fascist Italy were not impervious to antisemitic and racial prejudices. Looking at the discussion on race and anti-semitism in the propaganda of clerical Fascism and its simultaneous echo in Church discourses, this research delves deeper into the formation of a specific Catholic trend of racial antisemitism that excluded Jews from a religiously and ethnically homogeneous definition of the Italian nation. A significant part of the propagandists of clerical Fascism attempted to define a racial and anti-semitic narrative that could be suitable for both Fascist racism and Italian Catholic culture. I examine the Catholic appropriation of racial anti-semitism on a broad spectrum of positions, ranging from Catholics who only flirted with racialist rhetoric to those who dismissed the transformative value of conversion because of alleged racial barriers. Challenging the traditional distinction between Christian antiJudaism and modern anti-semitism, the examples under examination demonstrate the entanglement of religious and racial arguments in the shaping of a 'Jewish race' that was considered foreign to the italianità celebrated by the regime.
\end{abstract}

Keywords: anti-semitism; race; Vatican, Catholicism, Fascism, Jews

\section{Introduction}

On 18 July 1938, Father Mario Barbera, one of the editors of the Jesuit fortnightly La Civiltà cattolica, praised the anti-semitic provisions recently adopted in Hungary. At a moment when Mussolini's regime was about to launch its racial anti-semitic campaign in Italy, Father Barbera found that the Hungarian anti-Jewish measures were a legitimate reaction against the indestructible bond that ties all Jews together: "the instinctive and irrepressible solidarity of their nation around the common cause of their messianic fulfilment, which yearns for world supremacy' (Barbera 1938b, 150). ${ }^{1}$ Three months earlier, another article, probably by the same author, stressed the common denominator of Jewry as a whole: 'The unique singularity of Judaism lies in the fact that it is, at the same time and indissolubly, a nation and a religion, still present among Jewish apostates, because of the Talmudic messianism which persists in them' (Barbera 1938a, 76).

Far from being an isolated incident, the case of Father Barbera is indicative of a broader attempt to reconcile the Catholic Church and the Fascist regime on the question of race and antisemitism. This essay examines similar examples of Catholic authors and propagandists, clerics as

*Email: nina.valbousquet@gmail.com 
well as laymen, who attempted to find common ground between Fascist racism, anti-semitism, and Catholicism. In the scholarship on the 1938 racial laws in Fascist Italy, Catholic anti-semitism is sometimes reduced to an archaic, anti-modern and non-racial version of anti-Jewish hostility. Opposing the myth of Italiani brava gente (Bidussa 1994), a scholarly approach that emerged at the end of the 1980s has shed light on the pre-existing, national trends of anti-semitism and racism that had constituted a fertile ground for the adoption of the Fascist anti-Jewish legislation (Sarfatti 1994, 2000; Toscano 2003). In a longue durée perspective, part of this scholarship often incorporates colonial racism, racial anthropology, and social Darwinism among the nineteenth-century tendencies that merged into a national 'school' of racial anti-semitism during the Fascist regime (Burgio 1999; Bonavita, Gabrielli and Ropa 2005; Cassata 2011). In some scholars' works, the emphasis on the genealogy of Italian racism even leads to an intentionalist explanation of Mussolini's anti-semitism (Fabre 2005). Even though this approach offers stimulating investigations into previously unexplored fields, such as racial stereotypes in Italian literature (Bonavita, 2009), it does not extensively address the multiple articulations between religious anti-Jewish prejudices and colonial and pseudo-scientific racism. Furthermore, Catholic anti-semitism tends to be considered a separate category, distinct from nationalistic and secular anti-semitism, and therefore regarded as mild and old-fashioned compared to the totalitarian racial project of Italian Fascism in 1938.

I argue that some sectors of Catholic culture and politics under Fascist Italy were not impervious to racial prejudices and attempted to shape a Catholic narrative on Italian race and racism. The theoretical incompatibility between racism and Catholic teachings, as well as the Church's condemnation of the racial ideology of Nazi Germany, did not necessarily mean that an entrenched anti-semitic and racist mindset was not pervasive in Italian Catholic culture. While previous studies have underscored the ecclesiastical hierarchy's reactions to the 1938 racial laws as well as the Vatican's silence during the Holocaust (Zuccotti 2000; Fattorini 2007; Wolf 2010; Kertzer 2014), the diffusion and variegated manifestations of racial anti-semitism among different sectors of Italian Catholicism ought to be further explored and documented with new archival materials, especially for the first half of the Fascist period. However, recent studies in Italy have begun to shift the focus away from a top-down approach and to examine the grassroots, local, and cultural articulations of Catholic and Fascist anti-semitism (Facchini 2011; Mazzini 2013).

In this respect, this research draws specific attention to case studies of anti-semitic propagandists emblematic of the diverse sectors of clerical Fascism. Defined by John Pollard (2007) as a broad spectrum of clerics and lay Catholics who became 'fellow travellers' or 'flankers' of Fascism, these supporters of clerical Fascism bridged Catholic culture and political Fascist milieus. Rather than an overview on the manifold features and vectors of Church anti-semitism in Fascist Italy, this article focuses on the Catholic representations of race and their role in forging an ideological opposition between the 'Italian race' and the 'Jewish race'. I argue that in significant Fascist sectors of Italian Catholicism, the propagandist division between 'Italians' and 'Jews' was built not only on religious and social arguments, but also on racial prejudices.

While the study of the Vatican and the ecclesiastical hierarchy's responses to the Fascist racial campaign deserves a dedicated, in-depth examination, it does not constitute the main focus of this essay. That said, those responses serve as a contextual backdrop when considering the various factors that influenced the Italian Catholic world and the supporters of clerical Fascism within it. The circles of clerical Fascism and those of the institutional Church were connected on many levels and in complex ways (Ceci 2013; Guasco 2013). The specific issue of the Fascist racial campaign reveals a phenomenon of mutual awareness between both milieus: propagandists of clerical Fascism were attentive to the pope's utterances and attempted to serve as ideological 
intermediaries between the oftentimes conflicting views and prerogatives of Mussolini's regime and the Vatican. Conversely, officials of the Holy See were aware of the development of a propaganda model of clerical Fascism supporting the racial laws and they took that into consideration in the Vatican's responses to the anti-semitic campaign provided via its unofficial press. A question of particular interest for this research is to examine the extent to which there were commonalities and simultaneities in the racial discourses of clerical Fascism and the Church's institutional voices.

Drawing upon the groundbreaking works of Italian Church historians Giovanni Miccoli (2000) and Renato Moro (2002), this research delves deeper into the formation of an interconnection ('nesso fluttuante' as Miccoli phrases it, 2003) between a Christian anti-Jewish tradition and modern anti-semitism. Challenging the dichotomy between the two oft-invoked but largely artificially separated categories of modern anti-semitism and Christian anti-Judaism - a distinction created in large part post hoc in documents about the Holocaust by the Vatican and by apologists (Mazzini 2010) ${ }^{2}$ - this research contributes to a growing historiography that reassesses the role of religion in the making of racial anti-semitism. Far from being merely religious, Catholic anti-semitism shaped a derogatory image of the Jew that was in large part social, political, and racial - according to the definition of racial anti-semitism discussed by Yosef Yerushalmi in his pioneering works (1982). Casting doubts on conversion as a traditional 'solution' to the 'Jewish question', Catholic antisemites considered that Jews were inherently and inevitably malevolent and as such irredeemable. To be sure, this perspective is not a particularity of the Italian context, as recently demonstrated by historian John Connelly (2012) in his study on German and Austrian Catholics. Yet, the entangled histories of modern anti-semitism and Christian anti-Judaism still deserve further attention in the scholarship on Fascist Italy.

\section{The longue durée and blurred lines of Catholic anti-semitism in Italy}

Manifestations of Catholic anti-semitism during the Fascist regime remained undoubtedly embedded in the nineteenth-century legacy of the Church's firm opposition to the unification of Italy under a liberal and secular leadership. According to Giovanni Miccoli, anti-semitism offered a powerful means of Catholic mobilisation against liberal and anti-clerical policies in the broader context of the 'Roman Question' and the conflict between the national liberal state and the pontifical power (Miccoli 2003). Liberated from the yoke of the Catholic Church's restrictive legislation and emancipated thanks to Italian unification, Jews crystallised Catholic resentment against modernity and secularism. Anti-semitism was therefore included in the wider frame of the Church's fight against liberalism and against the civil rights granted to other religious minorities, not only Jews but also Protestants. It was also instrumental in the Catholic denunciation of the role played by liberals and freemasons in Italian politics. This lingering political and cultural clash fed anti-semitic discourses in the Catholic press (Di Fant 2002) as well as in popular literature (Capone 2016). As shown by historians David Kertzer (2001) and David Lebovitch Dahl (2003), throughout the nineteenth century the Church had recurrently called for the revocation of Jewish equality and for the introduction of new anti-Jewish laws (numerus clausus for instance) that could curb the alleged Jewish 'influence' on society.

During the interwar period and until 1938, anti-semitism found a fertile ground within some publications of the Catholic Church in Italy, not only (and unsurprisingly given their previous record of anti-semitic articles) in the unofficial journals of the Vatican (La Civiltà Cattolica and L'Osservatore Romano), but also in new titles of the Catholic press such as Vita e Pensiero from the Catholic university of Milan. As noted by historian Simon Levis Sullam (2011), an anti- 
semitic culture permeated broader sectors of the Catholic world, including both clerics and lay persons: firstly, through a traditionalist stream of cultural anti-semitism conveyed by notorious Catholic intellectuals, such as writers Giovanni Papini, Emilio Cecchi, and Domenico Giuliotti; secondly, in the form of a more virulent type of anti-semitism, grounded in conspiracy theories (Pichetto 1983), shared by nationalists, such as Giovanni Preziosi, a former priest, director of the pro-Fascist journal La Vita Italiana (and eventually General Inspector of Race during the Italian Social Republic), and by integralist Catholics, such as Umberto Benigni and his Tuscan journal Fede e Ragione.

Catholic antisemites in Fascist Italy continued to mobilise typical Christian anti-Jewish myths like the accusation of deicide and the conviction that God's punishment against Jews cursed them as a people fated to persecution. They also alluded to more complex theological arguments like the replacement theology according to which Christianity superseded Judaism as the faith of the chosen people and the Catholic Church was the Verus Israel, the 'real Israel'. These theological considerations could in some cases lead to a deterministic view of Jewish identity. Frequently stigmatised as 'Christ-killers', Jews were depicted not only in religious terms as unfaithful, blind, and obstinate, but also in social-economical terms as malevolent, duplicitous, and as a threat to Christian society. As such, the polysemy and the different interpretations of the liturgical expression perfidis Judaeis ('unfaithful' but also 'perfidious Jews') used in the Good Friday prayer were closely intertwined in the stereotypical image of the Jew created in this type of antisemitic literature (Menozzi 2014).

These traditionalist views were carried by integralist Catholics such as Msgr Umberto Benigni, long-standing promoter of Italian anti-semitism before Fascism and who presented himself as an expert 'scholar' of blood libels. Already in 1890, in his Il Piccolo Monitore (a weekly he founded in 1887 for the diocesan committee of Perugia), he stigmatised Jews as a 'race of butchers' (sgozzatori, Benigni 1890). Blood libels resurfaced throughout Benigni's literature, including in his renowned magnum opus as a Church historian, his five-volume Storia sociale della Chiesa, published by Vallardi between 1906 and 1933 and stamped with the approval of the archdiocese of Milan (the imprimatur). These accusations of ritual murders drew on the powerful suggestion of blood and played on ambiguous lines between religious and racial identities. As demonstrated by historian David Biale (2007) and anthropologist Joanna Tokarska-Bakir (2015), blood libels carried a biological definition of Jewish difference. This explains why, despite their antiquated, medieval appearance, this kind of Christian anti-semitic stereotype was recycled in the illustrated magazine of Fascist racism, La Difesa della Razza, created specifically to support the racial campaign of the regime and dedicated to the promotion of the virtues of the Italian race (Servi 2005; Cassata 2008). Despite its claims of modernity and pseudo-scientific racism, La Difesa della Razza capitalised on a repertoire of Christian anti-Jewish prejudices. Yet, racist journalists of the official magazine felt the need to insert a disclaimer that using Church anti-semitism was not 'anachronistic' at all (Porfiri 1940).

Another recurrent feature of Umberto Benigni's propaganda, not to mention of Catholic anti-semitism from the end of the nineteenth century to the interwar period, was to label Jews as an Oriental race. Their designation as 'Semites' inevitably made them strangers to the Latin italianità. In the 1906 and 1915 volumes of his social history of the Church, Benigni considered Jews to possess the archetype of an Oriental mindset, depicted in derogatory terms: 'the greedy and stingy Oriental as exemplified by the typical figure of the Jew, [with his] simplistic mentality'. He contrasted this Jewish 'miserly spirit' with the Christian and Italian 'generosity, which is a typical quality of our race' (Benigni 1906, 350; 1915, 276). Benigni also propagated his anti-semitic views in broader intellectual and cultural milieus. For instance, in 1922-1923, 
he published various articles in the neoclassic literary review La Ronda, founded in Rome in 1919 by well-known Catholic writer Emilio Cecchi. In La Ronda, Benigni commented on the historical work of Gaetano de Sanctis (Storia dei romani) and argued that because of their Oriental mentality, Jews as 'Semites' had always been a threat to the Roman-Greek world and to its legacy (Benigni 1922).

\section{From anti-modern Catholicism to clerical Fascism}

As exemplified by Benigni, the trend of integralist Catholicism did not limit the extent of its antisemitic polemics to the legacy of Christian antisemitisn and to the nineteen-century conflict between state and Church. It also bears witness to the dissemination of a renewed mix of racial, political, and religious prejudices against Jews during the Fascist period. Before the 1938 racial campaign, integralist and anti-modern Catholics participated in the shaping of a 'Jewish race' that was deemed a threat to the true identity of Catholic Italy.

While some aspects of Benigni's role within Italian literary and cultural circles have been recently studied - notably his exchanges with Emilio Cecchi (Rigano 2008; Pischedda 2015) - the scope of his transnational connections and the full extent of his political activities during the Fascist regime have remained in large part neglected by scholarship (Valbousquet 2017a, 2019). A priest and journalist from Perugia, well-known professor of ecclesiastical history, and member of the Roman Curia under Pius X's pontificate, Benigni spearheaded an informal party of integralist Catholics, the most traditionalist and anti-modernist branch within the Church (Poulat 1977). With the more moderate pontificates of Benedict XV and Pius XI, Benigni became marginalised and led a right-wing internal opposition to Secretary of State Cardinal Gasparri. In the aftermath of the Great War, he founded a new counter-revolutionary Catholic network with a more political outlook, renamed Intesa Romana di Difesa Sociale in 1923. The same year, as he embraced clerical Fascism, he became a paid informer for the regime, first at the service of the Ministry of Foreign Affairs, and from 1928 to his death in 1934, directly for the polizia politica at the Ministry of the Interior.

In the aftermath of the First World War and the Bolshevik revolution, anti-semitism became utterly central to Benigni's counter-revolutionary network and propaganda. Thanks to his transnational connections, Benigni imported the anti-semitic forgery Protocols of the Elders of Zion into Italy. His Italian translation was published in March-June 1921 in the clerical anti-modernist journal Fede e Ragione, which was printed in Fiesole by his close friend, the journalist priest Paolo De Töth, and with the support of the bishop, Msgr Giovanni Fossà. Italian Jewish communities protested at the publication of the Protocols. Rabbi Dante Lattes sent a letter to Fede e Ragione and to La Vita Italiana (whose director Preziosi had also published the Protocols in February 1921) on behalf of the Federazione sionistica italiana, the foremost Zionist organisation in Italy. Fede e Ragione took advantage of Lattes' protest to directly attack Italian Jews in its conclusive commentary on the Protocols on 26 June 1921, stating that 'the venerable Rabbi Dante Lattes scrupulously implements the Protocols', and concluding that 'Semites' like Lattes could not offer any contribution whatsoever to 'Italian dignity' (FeR 1921b, 45). In doing so, Fede e Ragione created an antagonism between 'Semites' and 'Italians' and excluded Italian Jews from the national community. Even prior to the official Fascist anti-semitic campaign, Benigni's group contributed to nationalising and racialising the 'Jewish question' in Italy.

Integralist Catholics did not hesitate to cast doubt on the efficiency as well as the sincerity of Jewish conversions to Catholicism. They constantly reiterated that the 'Jewish imprint', the unchangeable, despicable nature of Jews, could not be erased. In various instances, Benigni 
claimed that his group of Catholic activists did not hate Jews because they were a different or inferior race, but only because they were the 'race enemy' of Christianity (Archivio Storico Diplomatico del Ministero degli Affari Esteri, Fondo Benigni, b. 28, bulletin 'Israël et le monde', 1921). To be sure, this hostility was not based on purely racial features but on the alleged behaviour of Jews. Nonetheless, according to a deterministic view of Jewish identity, the anti-Christian malevolence of the Jews was considered to be deeply imprinted into Jewish mentality since the 'deicide'. For instance, the Fede e Ragione version of the Protocols stated that 'cunning like an old fox, nervous like a young monkey, the son of the ghetto leaves everywhere he passes an indelible and unmistakable trace of himself' (FeR 1921a, 4). Bearing witness to a seemingly paradoxical mix of religious, social, and political stereotypes, integralist Catholics even embraced racial antisemitism, although not in the same terms as pseudo-scientific racism. While Benigni defined Jews a 'wicked and perfidious race' and a 'painful leprosy' (Benigni 1923), Count Filippo Sassoli de Bianchi, director of Fede e Ragione, asserted that 'the Jewish phenomenon cannot be considered as a mere religious fact, but rather as a fact that proves the existence of a race'. In this 1924 review of an anti-semitic pamphlet published by French Catholic Roger Lambelin on the 'Jewish peril', Sassoli de Bianchi considered Jews as a nation-race: 'this people, unique on earth, who have remained unchanged for 2,000 years, even though they are dispersed all over the world and among all peoples and nations, confirms tenaciously and in a mysterious way its own race, its own national individuality' (Sassoli de Bianchi 1924).

The main financier of Fede e Ragione thanks to his family wealth, Count Filippo Sassoli de Bianchi was not an unknown figure in Italian Catholicism: a member of the lay Dominican third order and a prominent figure of Catholic Action in Bologna, he presided for instance over the Ninth National Eucharistic Congress, alongside his close friend Cardinal Tommaso Pio Boggiani (Archbishop of Genoa 1919-1921, and then consultor of the Holy Office). Sassoli de Bianchi was among the early supporters of the Centro Nazionale (National Centre), the first Catholic organisation to articulate clerical Fascism as a political project in 1924 (Baragli 2011). Benigni also contributed to this first wave of clerical Fascism in the 1920s in his role as informer for the Fascist police. Through his reports sent to the Fascist police, Benigni pleaded the cause of a Roman version of racial anti-semitism while strongly opposing Nazi racism for its inherent anti-Christian and anti-Latin characteristics. As he put it in a 1933 report, Benigni considered both Judaism and Nazism as anti-Catholic and anti-Latin forces. According to Benigni, Nazism was the 'actual Siamese twin of Israel' because of its ambition of world domination and its racial hierarchy, which considered Italian and French 'Celto-Latins' (celto-latini) a " "brown race", intermediate between the pure Germanic race and the Semites' (Archivio Centrale dello Stato [hereafter ACS], M. Interno, Polizia Politica, Materia, b. 44, f. 4, report 'Antiromanesimo hitleriano' 18 May 1933). Because of his anti-Nazi position, Benigni argued against groups of Italian antisemites who favoured German neo-pagan anti-semitism, including collaborators of Preziosi's La Vita Italiana, most notably Julius Evola. A theorist of 'spiritual racism' and neo-paganism, Evola had been previously criticised on similar grounds in Fede e Ragione by young Catholic writer Piero Bargellini (who later became Christian Democrat mayor of Florence in 1966 [Bargellini 1928]).

To some extent, integralist Catholics were emblematic of a broader transformation of Catholic anti-semitism under the Fascist regime. With the collapse of the liberal state and the advent of Mussolini's dictatorship, it became more difficult and less relevant for Catholics who rallied to the regime to draw upon anti-semitism as part of a narrative of a Catholic counter-culture opposed to the Italian unification, especially after the Lateran Pacts of 1929. In a broader phase of nationalisation of Italian Catholicism (Moro 2004), Catholic propagandists reoriented their antisemitic 
discourse toward a celebration of the Roman character of Fascist Italy, which incorporated Catholicism as a genuine and vital feature of an ethnically defined Italian identity.

\section{Clerical Fascism: presenting the Italian racial laws as 'Christian' policy}

Anti-semitism, both latent and overt, was a key feature of some of the most enthusiastic promoters of clerical Fascism of various affiliations, from moderate conservatives to integralist antimodernists. As noted by Renato Moro (2003), a significant percentage of antisemitic publications during the Fascist campaign against Jews originated from authors who claimed at the same time Catholic and Fascist affiliations. Most of these authors were active before 1937-1938, so that a repertoire of Catholic anti-semitism had already been available for the regime's propaganda. The antisemitic campaign in the Fascist press was informally launched during the spring of 1937 by the pamphlet Gli ebrei in Italia written by Paolo Orano (Orano 1937, Battini 2010, Valbousquet 2017b). Deputy, professor, and journalist close to Mussolini, Orano had reiterated - since his 1898 book Il Problema del cristianesimo - that Christianity was quintessentially Latin and Roman and had therefore no ties with Judaism, which instead remained irremediably embedded in the 'primitive fierce sadness' of an Oriental mindset; Catholics and Jews were so dissimilar that they constituted 'two different mental outlooks' (Orano 1898, 44, 141).

Some Catholics willingly contributed to the Fascist antisemitic campaign and to the 'debate' on the nature of racism in Italy. Within Fascism, they advocated the adoption of a state-driven antisemitic policy that could remain distinct from Nazi anti-semitism and comply with the Catholic and Latin traditions of Italy. Beyond ideological commonalities, there was also a purely strategic consideration for Catholic antisemites who aimed to prevent any potential accusation of 'pietism' (pietismo) against them and the Catholic Church. Indeed, radical Fascist antisemites, like Roberto Farinacci, blamed Catholics for their lack of enthusiasm toward racism and for expressing too much sympathy with persecuted Jews. However, the same radical Fascists claimed that Italian racial laws were perfectly in line with the anti-Jewish tradition of the Church (Farinacci 1938, 7; De Felice 1993, 322-323). Like Farinacci, Giovanni Preziosi capitalised on the antisemitic record of La Civiltà Cattolica as evidence of the Church's deep-rooted hostility toward Jews. In La Vita Italiana of May 1938, Preziosi quoted extensive excerpts of Barbera's article of 2 April - which, as previously mentioned, defined Jews as an indissoluble nation - considering it 'a summary of the Jewish question so perfect' that it should repel any temptation of 'pietism' on the Catholic side (Preziosi 1938, 657).

One of the main discursive strategies of the Catholic strain of anti-semitism in order to give more legitimacy to the Fascist racial campaign was to present the antisemitic laws as a self-defence of Christian civilisation. This argument was recurrent in various instances of clerical Fascism, such as the publications of Mario Lolli (Lolli 1938) and Carlo Cecchelli. The latter dew a direct line between Church anti-Jewish measures and Fascist racism in his articles published in the widely distributed Milan-based daily, Corriere della Sera, during the summer and autumn of 1938, as well as in his book La questione ebraica e il sionismo, published in 1939 by the National Institute of Fascist culture (Cecchelli 1938a, 1938b, 1939).

A scholar of Christian archaeology, Carlo Cecchelli was an official in the religious affairs department of the Ministry of the Interior at the time of the racial laws. Coming from a mainstream trend of national, moderate Catholicism, Cecchelli celebrated the greatness of the 'Italian race', from which he excluded Jews. In one of his articles for Corriere della Sera-reproduced in a 1939 volume edited by Paolo Orano entitled Inchiesta sulla razza - Cecchelli argued that the racial background of an individual was shaped by multiple factors, including history and tradition. Each 
individual consisted of a unique soul shaped by God (the 'limpid image of the Creator') and features of the appropriate race and national spirit. Understood as a mix of both psychological and biological characteristics, race was shaped not only by geography and demography, but also by a "patrimony of ideas and human experiences of the social body, which can be designated as tradition' (Cecchelli 1938a). Drawing upon this historical-spiritual definition of race, the author could then assert than the Italian people, having lived in the same territory for centuries and without any major interference of 'foreign elements', formed a homogeneous race, characterised notably by the 'somatic continuity of many elements of the Italic civilisation'. According to Cecchelli, the culture of the Roman empire and the Catholic Church had decisively shaped and enhanced this homogeneity of the Italian race: 'the idea of Roma contributed to this ethnic cohesion and also - we must acknowledge it - the Church of Rome'.

This rhetorical discourse was also used to forge a Jewish identity utterly foreign to the definition of italianità. Even though he acknowledged some 'Oriental influences' in the history of Italy, Cecchelli denied the Jews, who had been living in Italy for many centuries, any demographic and cultural impact on the Italian race: 'the Jewish contribution (people who came as slaves or merchants) is minimal. More than the Arab, the Jew [giudeo] has borne witness to a strong interpenetration of ethnic community and national religion, and has demonstrated a deep aversion toward mixed marriages'. Because of the entanglement of ethnic, national, and religious characteristics as well as the generalisation of endogamy, Cecchelli concluded that the 'Jewish people' was unique and that Jews remained unchanged: 'the geographical environment and the social aggregate have had only secondary effects on Jewish nuclei, and have not succeeded in degenerating this extraordinary people, which has maintained everywhere its cohesion, and has also preserved many of its biological features'. In these lines, which echoed those of Sassoli de Bianchi in Fede e Ragione some 14 years beforehand, Cecchelli did not hide a sort of fascination for the persistence of the alleged uniformity of the Jewish race, even in biological terms, making it a 'compact Semitic group'.

\section{Shaping a Catholic, 'acceptable' variation of racism}

Other examples of Catholic-Fascist antisemitic publications surfaced throughout the racial campaign of the Fascist regime. Although traditional Christian anti-semitism was not the first option adopted by the official antisemitic campaign during the summer of 1938, it was still influential within Italian Fascism. The strictly racial-biological framing of the Manifesto degli Scienziati razzisti (the so-called Manifesto della Razza), edited by Mussolini (Toscano 1996, Gillette 2001) and published on 14 July 1938, generated disputes and contestations in Italian antisemitic milieus that saw the Manifesto as a servile imitation of Nazi Germany. These antisemites promoted instead a more Italian, spiritual, and traditional version of anti-semitism. As demonstrated by recent scholarship, the regime did not censor these internal criticisms and saw in this zealous competition between different propaganda groups for anti-semitism and racism an opportunity to increase the totalitarian mobilisation for the new antisemitic policy (Matard-Bonucci 2008, Germinario 2009). According to Mauro Raspanti, Fascist racism was divided into three sub-trends competing against each other in a power struggle for the monopoly of the official racial ideology of the regime: biological racism (razzismo biologico), esoteric-traditionalist racism (razzismo esotericotradizionalista, mainly represented by Julius Evola and articulated around neo-pagan elements), and national racism (nazional-razzismo) (Raspanti 1994, 73). Only the latter was accepted and even in some instances encouraged by Catholic publications and Church officials. The Jesuit Fathers of La Civiltà Cattolica sought for an overlap with the regime on a nationalistic variant of 
racism that could enhance the role of tradition, and therefore of the Catholic Church, in the shaping of Italian ethnic identity (Taradel and Raggi 2000, 115).

The fact that the nationalistic and Christian version of racial anti-semitism was able to expand throughout the racial campaign proved that the Fascist regime was not exclusively focused on biological and Nazi-inspired racism but was also willing to find a compromise with the Catholic tradition and to experiment with a variety of ideological configurations. La Difesa della Razza did not neglect Catholic authors such as Herman de Vries de Heekelingen, who was praised as one of the great 'international thinkers' of racism (de Vries de Heekelingen 1939). A Dutch member of the Dominican lay third order and professor of palaeography at the Catholic University of Nijmegen, he became at the end of the 1920s an internationally recognised Fascist activist and antisemitic propagandist in France, Switzerland, Germany, and Italy. In France, he published successful pamphlets like Israël, son passé, son avenir (1937, translated into Italian the same year by Tumminelli), L'Orgueil juif (1938), and Juifs et catholiques (1939). His books drew upon a variety of antisemitic materials that ranged from the works by French and Italian Catholic antisemites (Msgr Jouin, Msgr Delassus, Roger Lambelin, Benigni), as well as German sources like the Antisemitic Catechism of Theodor Fritsch (1893) and the more contemporaneous racist publications of the Weltdienst in Erfurt.

De Vries de Heekelingen's publications received a great amount of attention and overall positive reviews in La Civiltà Cattolica. Commenting on Israël, son passé, son avenir, in May 1937, Father Barbera praised the seriousness and the expertise of the author and especially the 'documentary' value of his reliable materials (Barbera 1937a, 421-422). While Barbera completely agreed with the book's emphasis on the inherent malevolence of Jews as a whole, he departed from the practical 'solutions' suggested by the Dutch author to the 'Jewish question'. Indeed, de Vries de Heekelingen saw Zionism as a potential relief for the nations that had to 'host' Jews: a concentrated migration that could alleviate nations from the burden of Jewish influence. Barbera opposed this positive view of Zionism and argued that, even if they could obtain their own territory and state, Jews would not change substantially and would remain the same eternal cosmopolitan revolutionaries: 'even if the Zionist state were established, millions of sons of Israel would remain scattered all over the world, not substantially changed from what they are today: speculators and rakers-in [rastrellatori] of gold, and messianic revolutionaries. . . Politics will stem them only on the surface, and will leave them as they are in their innermost being' (Barbera 1937b, 497).

With his position of intermediary between Fascism and the Church and his combination of religious and racial stereotypes, de Vries de Heekelingen proved to be appealing to Fascist officials, who considered drawing on his publications for the regime's antisemitic campaign. On April 1939, the Italian Ministry of Foreign Affairs believed that his Juifs et catholiques could be cited for its main argument of a Latin antisemitic continuum stretching from the Church's medieval canonical legislation to the Italian Fascist anti-Jewish laws. Regarding this publication, an official of the Ministry reported to Mussolini: 'This book, interesting for its documentation and bibliography, is an efficient element for antisemitic propaganda and for racist studies' (ACS, Segreteria particolare del duce, Corrispondenza ordinaria, f. 530341 de Vries de Heekelingen, memo from the Cabinet of Foreign Affairs to the SPD, 10 April 1939). Such an assessment of the value of de Vries de Heekelingen's Catholic antisemitic works shows that the regime intentionally sought for different approaches to the question of race in its antisemitic propaganda.

Indeed, the Dutch professor was then promoted to official propagandist of Fascist antisemitism and was commissioned to write a booklet directed at foreign audiences in order to legitimise the Italian racial laws as a national and Christian-inspired policy. Published in June 
1940, L'antisemitismo italiano was translated and distributed in France, Japan, Switzerland, and Germany among other countries, thanks to the official support of the Fasci all'estero (Italian Fascist organisations abroad). In this booklet, de Vries de Heekelingen argued for a strict separation between Jews and Christians, in direct continuity with Church policies of ghettos and the 'double protectorate'. As such, the Fascist interdiction of intermarriages happened to be justified by the ecclesiastical tradition itself: 'The directive principles of the Church since the fifth century have been renewed in the recent Fascist laws. The Church has always forbidden marriages between Jews and Catholics. The Italian law forbids marriages between Jews and Italians' (de Vries de Heekelingen 1940, 15). Part of his discursive strategy aimed to respond to Catholics who may have protested, or could be tempted to protest, against the racial laws. The author did not hesitate to call them marranos, a derogatory term for New Christians (Jewish converts) in early modern Spain.

\section{The ambiguities of the Vatican's positions on race}

The emphasis that clerical Fascism put on presenting the racial laws as Christian-inspired is ultimately indicative of actual tensions between the Fascist regime and the Holy See, especially on the definition of a form a racism 'suitable' for Italian Catholics. The Vatican and the large majority of the Italian ecclesiastical hierarchy did not oppose or explicitly challenge the 1938 antisemitic provisions. Although the Vatican rejected violent antisemitic persecutions and Nazi racial antisemitism, special laws of 'defence' of Christians against Jews remained appealing for the Church as a 'reasonable' middle ground between Nazism and liberalism. Only two specific issues raised criticisms from the Church: there was initial concern that Fascist anti-semitism would be a copy of anti-Christian Nazi racism and, more importantly, opposition to the Fascist prohibition of intermarriage, essentially because it infringed provisions of the 1929 Concordat (Miccoli 1988, Perin 2013).

Facing the participation of Catholic propagandists in the Fascist antisemitic campaign and the instrumentalisation by the Fascist regime of the Church's own record of anti-Jewish teachings and policies, the Vatican insistently stressed the theological incompatibility between racism and Catholicism. On three different occasions, shortly after the publication of the Manifesto della razza, Pius XI denounced the Nazi orientation of the Fascist racial campaign (15, 21, and 28 July 1938). Speaking in front of the students of the College Propaganda Fide on 28 July, the Pope condemned 'exaggerated racism and nationalism' and lamented that Mussolini had felt compelled to imitate Nazi Germany. Even though Pius XI clearly asserted the absolute opposition between racism and the universalism of the Catholic Church, he did acknowledge the existence of different races coming from the same origin: 'the human genre is one unique, universal, Catholic race. One cannot deny however that in this universal race there is room for special races, as many diverse variations, as many nationalities which are even more specialised'. Therefore, the universal mission of the Church was not incompatible with a certain degree of racial differentiation: 'alongside this universalism, there are of course many things, naturally, in their place, but which seem to be forgotten: the idea of race, of lineage [stirpe], the idea of nation, of nationality' (Taradel and Raggi 2000, 113). ${ }^{3}$

The Pope's condemnation of racism was not incompatible with the formulation of racial considerations within Vatican internal debates, for instance in those regarding intermarriage. Colonial racism and the fear of interbreeding were barely hidden in the various Vatican officials' memoranda for the elaboration of the Pope's reply to Mussolini's interdiction of mixed marriages. For instance, the draft submitted by the nuncio to the Italian government, Msgr Francesco 
Borgongini Duca, on 21 October 1938, stated that even if the Church could not, in virtue of divine law, forbid marriages between Catholics of different races, it was its duty to prevent the harm of such mixed unions: '[The Church] discourages with all the arguments at its disposal, for moral and hygienic reasons, unions between whites and blacks and any kind of heterogeneous union, also to avoid the formation of half-breeds, who combine all the flaws of the different races that are being mixed'. The draft written two days later by Msgr Domenico Tardini (secretary of the Congregation of Extraordinary Ecclesiastic Affairs, Vatican equivalent of a ministry of foreign affairs) summed up the role of dissuasion played by the Church against 'too heterogeneous crossbreeds of races, which often lead to unhappy outcomes' (Archivio Segreto Vaticano, Nunziatura Italia, b. 9, f. 5).

Regarding Jews, the vocabulary was less racial but the principle of a strict separation and the fear of mixed unions remained prominent. On November 13-14, the Vatican official newspaper L'Osservatore Romano tried to play down the extent of the conflict between the Church and the Fascist regime on the question of intermarriage in an article partly drafted by Cardinal Secretary of State Pacelli. The Vatican unofficial mouthpiece was pleased to observe that 'religious marriages celebrated between persons of different races are extremely rare, and this rarity is favoured by the very low inclination of Catholics and Israelites to unions with persons of other races' (Archivio Segreto Vaticano, Nunziatura Italia, b. 9, f. 5). In the conflict over intermarriage, Church officials raised their voices first and foremost in defence of marriage between Catholics and Jews who had already converted to Catholicism; marriage between Catholics and non-converted Jews remained forbidden by canonical law with some rare cases of pontifical exemptions.

Nonetheless, even the discourse on Jewish converts was sometimes imbued with racial considerations. In his May 1937 article commenting on de Vries de Heekelingen's book, Father Barbera, after having excluded Zionism as a potential solution, reassessed conversion as the traditional Christian response to the 'Jewish question'. A Catholic mission, conversion was, however, not considered entirely sufficient according to Barbera (Barbera 1937b, 500-501). Firstly, in the case of individual conversions, Jews would lose their 'Judaic nationality' only at the 'second or third generation'. Secondly, the collective conversion of Jewry as a whole remained completely 'unlikely'. Thirdly, the few individual conversions could 'not change the rest of Judaism; thus, they leave as it is the Jewish question'. Consequently, a 'temporary solution' had to be found in the traditional anti-Jewish policies of the Church, which aimed at separating Jews from Christians, establishing a 'friendly segregation' (segregazione amichevole) allegedly protecting both Jews and Christians from each other. To some extent, this was the same 'solution' that the Fascist regime claimed it was implementing.

\section{Reconciling Church and Fascism, Catholicism and race}

Representing the prevailing opinion among mainstream Vatican circles, La Civiltà Cattolica was willing to find a version of national racism that could meet the ideological and strategic expectations of both the Italian Catholic Church and the Fascist regime. In January 1939, after the appeasement of the conflict on mixed marriages, Father Antonio Messineo, one of the foremost editors of the Jesuit quarterly, published an article entitled Alla ricerca di una soluzione. Chiarimenti e distinzioni (Messineo 1939). Claiming a right for Catholics to intervene in the racial debate, Messineo favoured a more 'spiritual' understanding of race that could overcome the strict materialism of German racism; for that reason, the term stirpe (lineage) was preferred over that of race.

This search for a suitable version of Italian racism was at the same time being pursued by propagandists of clerical Fascism who were anxious to find and to maintain after 1938 a 
compromise between the long-term roots of Catholic traditions in Italy and the totalitarian racial and demographic aspirations of the Fascist regime. An active member of the Centro Nazionale and an influential exponent of the monarchist and moderate Catholic tendencies within Fascism, Giulio de' Rossi dell'Arno was among these activists involved in the mediation between Catholicism and racism until the very end of Mussolini's regime (Giulio de' Rossi dell'Arno, 1927, 1932). His way of addressing the tensions between Church and Fascism on the racial question was twofold.

First, he argued that Catholics who criticised the racial campaign of the Fascist regime were misinformed and manipulated. In an article published in October-November 1938 in Rassegna Nazionale, the monthly he had edited since 1936, de' Rossi dell'Arno blamed, without naming them, Pius XI and the Jesuit editors of La Civiltà Cattolica who during the summer had tried to discredit Italian racism as an 'imitation' of Nazism (de' Rossi dell'Arno 1938, 568). This allegation of imitation, which denied the 'genial originality of Italian racism', was unfounded and absurd according to de' Rossi dell'Arno, for the Church itself had contributed, thanks to the Lateran Agreements, to the creation of a 'perfect moral unity' among Italians, the first, necessary foundation of Italian racism. This religious and spiritual unity had laid the ground for the fulfilment of the Italian race and the 1929 Conciliation became the 'bedrock of a realistic and concrete racial policy'. In January 1939, another article by the director of Rassegna Nazionale charged Catholics who dared to criticise Italian racism of complicity with cosmopolitan anti-Fascist groups with acting for the sole benefit of 'Judeo-bolshevism' (de' Rossi dell'Arno 1939, 19).

Second, like Benigni, Cecchelli, and de Vries de Heekelingen before him, de' Rossi dell' Arno offered his own interpretation of the compatibility of Italian racism with the defence of Christianity. In his view, Fascist racism was 'profoundly human' and as such poles apart from the pagan racism of Nazi Germany and the 'anti-human racism' of British imperialism (de' Rossi dell'Arno 1938, 563). Unlike German racism, the Fascist racial campaign did not venerate pantheism and paganism but formed instead a bulwark against atheism and materialism. With a syllogism emblematic of his rhetorical style, de' Rossi dell'Arno argued that the first aim of Fascist racism was the integral defence of Italian tradition; because this tradition was essentially Roman and Catholic, the racial policies of the Fascist regime were therefore an act of defence of the Roman Church. In the vein of Benigni's 1920s propaganda, de' Rossi dell'Arno asserted that Jews being the first and foremost enemy of the Roman and Catholic spirit of the Italian race, a racial policy that targeted them and curbed their influence was absolutely legitimate from a Christian point of view. In his January 1939 article, he also attempted to legitimise racism from a theological standpoint:

One cannot understand why the Catholic opponents to racism hit the ground running to defend the Revealed Truth of the common origin of humankind since Adam. Italian racism does not offend or deny this Revealed Truth. Peoples originated from a unique human stock [ceppo] created by God, and then, according to a providential and unfathomable design, they became different from each other to such an extent that Catholic missionaries themselves pointed to the threat of crossbreeding [meticciato] leading to the decadence of the human genre. (de' Rossi dell'Arno 1939, 19)

In Rassegna Nazionale, as in Cecchelli's articles or in the Vatican officials' reports, the mindset of colonial racism resurfaced frequently and remained in the background of Catholic debates on race even when they dealt primarily with antisemitic persecutions. The fear of mixed races seems to serve as the ultimate argument to prove the existence of different races as well as the necessity to set some racial barriers and separations, while claiming to maintain Christian principles of 'charity' and 'justice'. 
One of the discursive strategies that distinguished de' Rossi dell'Arno in the antisemitic literature of clerical Fascism is his specific emphasis on rural Italy as a stronghold of the authentic Italian race, which he contrasted with the degenerate urban life typical of 'bourgeois' and cosmopolitan Jews. According to the director of Rassegna Nazionale, Italian peasants shared an intuitive sense of race and had practiced racism for centuries without even being aware of racial theories. Rural priests knew perfectly how to respond to peasants' strong aversion to mixed races, through the celebration of marriages between men and women from the same ethnic and geographical origins. In a language reminiscent of Fascist political religion, de' Rossi dell'Arno depicted countryside weddings as both a religious and racial ceremony: 'a moving racist ritual'. In this perspective, the local clergy was assigned a crucial role in the implementation of everyday racism: 'the rural priests have always favoured the sincere Italian racism, which preserves the physical and moral life in every [peasant]' (de' Rossi dell'Arno 1938, 566-567). These were not only rhetorical words uttered by de' Rossi dell'Arno, they also mirrored his specific activism, which had targeted the Catholic countryside since the 1920s. For instance, in 1929, he created the Concorso del Grano fra Parroci e Sacerdoti, a clerical version of the 'Battle for Grain', supported by the regime (Araya 2014).

\section{Conclusion: beyond 1938}

As exemplified by de' Rossi dell'Arno, who published in 1940 a volume entitled L'Ebraismo contro l'Europa, clerical Fascist anti-semitism persisted during the war and as the repercussions of the racial laws became more visible. The same could be said for Guido Aureli, long-term collaborator of Msgr Benigni and one of the last representatives of the older generation of integralist Catholics, who published in June 1941 an antisemitic and anti-British pamphlet Bombardiamo San Pietro! (Churchill junior ai Comuni, dic. 1940). Ebraismo, massoneria e anglicanismo contro la Chiesa di Roma.

These were not isolated examples contained in a single stream of Fascism or Catholicism, as some Church publications also continued to explore potential overlapping ideological configurations between Catholicism and Fascist racism. Between December 1942 and March 1943, Father Barbera dedicated five lengthy articles to the Trattato di Biotipologia umana published in 1939 by Nicola Pende, praising its 'well-balanced concept of race' and embracing the celebration of the 'Roman-Italic race' (razza-romana-italica [Barbera 1943, 229]). One of the signatories of the Manifesto degli Scienziati Razzisti, Pende argued, against the strictly biological racism of his rival Guido Landra, that race was the result of a variety of factors, including environment, culture, tradition, spirituality, and crossbreeding with similar ethnic groups. This nationalistic and sociocultural understanding of racism fell in line with the new, mainstream orientation given by the regime to the racial campaign after the fall of 1938 (Israel and Nastasi 1998, Maiocchi 1999). Denying the existence of a 'pure race', Pende preferred the concepts of stirpe and 'race-synthesis' (razza-sintesi), which could sound more 'acceptable' to Church ears. Indeed, at the end of his extensive comment on Pende's volume, Father Barbera concluded that these views on race were 'substantially synchronised' with the Catholic doctrine (Barbera 1943, 233; Taradel and Raggi 2000, 122-123). Barbera's praise resulted from an explicit willingness to find a common definition of race between Church and Fascism, as well as bearing witness to the longstanding presence of racial and antisemitic prejudices within some Catholic sectors.

Looking more closely at the diversity of the Italian Catholic world, especially among the ranks of clerical Fascism, provides evidence of a trend of Christian racism and anti-semitism that often tried to dissociate itself from Nazism. Despite condemnations of Nazi racism as an un-Christian 
ideology, some churchmen and lay Catholics continued to promote a 'legitimate defence' against the 'Jewish race'. In this process, the visible use of an age-old Christian anti-semitism by Fascist propaganda as well as the willing participation of some Catholics in the shaping of a definition of race that could be suitable for the Italian context remained unchallenged and unaddressed by the Catholic Church.

\section{Acknowledgements}

I wish to sincerely thank Silvana Patriarca and Valeria Deplano for inviting me to participate in this special issue on racism. I am indebted to Ernest Ialongo and Natalia Indrimi for their comments on a paper I presented at the Columbia Seminar in Modern Italian Studies in February 2017, and to all the participants in the seminar: their questions and remarks helped me to reframe and improve the first draft of this essay. I am also grateful to Frances Tanzer for her close reading of my article.

\section{Notes on contributor}

Nina Valbousquet has been for two years (2016-2018) a Postdoctoral Fellow at the Center for Jewish History and Visiting Scholar at the Skirball Department of Hebrew and Judaic studies at NYU. She was awarded a fellowship at the USHMM in Washington DC (Autumn 2018) and a NYPL-Fordham University research fellowship in Jewish studies (Spring 2019). She completed her PhD in modern European history at Sciences Po Paris in 2016 and her dissertation will be published in Spring 2019 in France (CNRS editions). Her book proposal for a second monograph entitled Rome, Zion, and the Fasces: Italian Catholics and Antisemitism in Europe (1918-1946) won the 2017 Peter Lang Young Scholars Competition in Modern Italian Studies (forthcoming 2019). Her published and forthcoming articles appear in Revue d'Histoire Moderne et Contemporaine (2015), Cahiers de la Méditerranée, Modernism, Passato e Presente (2017), and Archives Juives and Journal of Modern Italian Studies (2018).

\section{Notes}

1. All translations from Italian into English are mine.

2. This distinction is instrumental in the Vatican statement on the Holocaust issued in 1998, 'We Remember: A Reflection on the Shoah', which denied any influence or legacy of Christian anti-Judaism in modern anti-semitism.

3. His speech was reproduced in L'Osservatore Romano on 29 July 1938.

\section{References}

Araya, T. 2014. 'Cattolicesimo, razzismo e fascismo. L'attività propagandistica di Giulio de' Rossi dell'Arno (1938-1943)'. Società e storia 143: 69-96.

Aureli, G. 1941. Bombardiamo San Pietro! (Churchill junior ai Comuni, dic. 1940). Ebraismo, massoneria e anglicanismo contro la Chiesa di Roma, Rome.

Baragli, M. 2011. 'Il Centro nazionale italiano e la Santa Sede. Profili e progetti del clerico-fascismo in Italia, 1922-1929'. Italia contemporanea 263: 239-254.

Barbera, M. 1937a. 'La questione giudaica e il sionismo'. La Civiltà Cattolica 2, May: 419-431.

Barbera, M. 1937b. 'La questione giudaica e le conversioni'. La Civiltà Cattolica 2, May: 497-510.

Barbera, M. 1938a. 'Intorno alla questione del sionismo'. La Civiltà Cattolica 2, April: 76-82.

Barbera, M. 1938b. 'La questione dei giudei in Ungheria'. La Civiltà Cattolica 2, July: 146-153.

Barbera, M. 1943. 'Biotipologia, orientamento professionale ed eugenica'. La Civiltà Cattolica 2, March: 225-233.

Bargellini, P. 1928. 'Risposta a Satana'. Fede e Ragione, 22 April. 
Battini, M. 2010. Il socialismo degli imbecilli. Propaganda, falsificazione, persecuzione degli ebrei. Turin: Bollati Boringhieri, 2010.

Benigni, U. 1890. Il Piccolo Monitore, 23 July.

Benigni, U. 1906. Storia sociale della Chiesa, vol. 1. Milan: Vallardi.

Benigni, U. 1915. Storia sociale della Chiesa, vol. 2, t. 2. Milan: Vallardi.

Benigni, U. 1922. 'I nuovi campi di Annibale'. La Ronda, July-August: 88-94.

Benigni, U. 1923. 'Gli Ebrei e il Cattolicesimo'. Rivista di Milano, December: 599-605.

Biale, D. 2007. Blood and Belief: The Circulation of a Symbol between Jews and Christians. Berkeley: University of California Press.

Bidussa, D. 1994. Il mito del bravo italiano. Milan: Il Saggiatore.

Bonavita, R. 2009. Spettri dell'altro. Letteratura e razzismo nell'Italia contemporanea. Bologna: Il Mulino.

Bonavita, R, G. Gabrielli and R. Ropa, eds, 2005. L'Offesa della razza. Razzismo e antisemitismo dell'Italia fascista. Bologna: Patron editore.

Burgio, A., ed. 1999. Nel nome della razza. Il razzismo nella storia d'Italia, 1870-1945. Bologna: Il Mulino.

Capone, A. 2016. 'Antisemitismo cattolico e letteratura popolare tra Otto e Novecento. Intorno all'opera di Ugo Mioni'. Studi storici 57: 389-422.

Cassata, F. 2008. La difesa della razza: politica, ideologia e immagine del razzismo fascista. Turin: Einaudi.

Cassata, F. 2011. Building the Common Man. Eugenics, Racial Sciences and Genetics in Twentieth Century Italy. Budapest: Central European University Press.

Cecchelli, C. 1938a. 'Origini ed omogeneità della razza italiana'. Corriere della Sera, 24 August.

Cecchelli, C. 1938b. 'La muraglia talmudica fra i giudei e gli altri popoli'. Corriere della Sera, 25 November.

Cecchelli, C. 1939. La questione ebraica e il sionismo. Rome: Istituto Nazionale di Cultura Fascista.

Ceci, L. 2013. L'interesse superiore. Il Vaticano e l'Italia di Mussolini. Rome: Laterza.

Connelly, J. 2012. From Enemy to Brother. The Revolution in Catholic Teaching on the Jews, 1933-1965. Cambridge, MA: Harvard University Press.

De Felice, R. 1993. Storia degli ebrei in Italia sotto il fascismo. Turin: Einaudi.

De' Rossi dell'Arno, G. 1927. Centro nazionale e Fascismo. Rome: Loescher.

De' Rossi dell'Arno, G. 1932. Cattolicesimo e fascismo: plebiscito dei vescovi per il regime. Rome: Edizioni di Italia e Fede.

De' Rossi dell'Arno, G. 1938. 'Razzismo italiano'. Rassegna Nazionale, September-October: 563-71.

De' Rossi dell'Arno, G. 1939. 'Cattolici e razzismo'. Rassegna Nazionale, January: 18-20.

De' Rossi dell'Arno, G. 1940. L'Ebraismo contro l'Europa. Rome: Maglione.

De Vries de Heekelingen, H. 1939. 'L'Eterna questione ebraica e la sua soluzione'. La Difesa della Razza, 5 November.

De Vries de Heekelingen, H. 1940. The Jewish Question in Italy. Florence: Felice Le Monnier.

Di Fant, A., 'La polemica antiebraica nella stampa cattolica romana dopo Porta Pia'. Mondo contemporaneo 3: 87-118.

Fabre, G. 2005. Mussolini razzista. Dal socialismo al fascismo, la formazione di un antisemita. Milan: Garzanti.

Facchini, C. 2011. 'Antisemitismo e chiesa cattolica in Italia (XIX-XX sec.). Ricerche in corso e riflessioni storiografiche'. Storicamente 7: 2-5.

Farinacci, R. 1938. La Chiesa e gli ebrei. Rome: Cremona.

Fattorini, E. 2007. Pio XI, Hitler e Mussolini. La solitudine di un papa. Turin: Einaudi.

FeR. 1921a. 'I Documenti della conquista ebraica del mondo, 1. I Protocolli dei saggi anziani di Sion. Introduzione'. Fede e Ragione, 27 March.

FeR. 1921b. 'I Documenti della conquista ebraica del mondo, 1. I Protocolli dei saggi anziani di Sion. Conclusione'. Fede e Ragione, 26 June.

Germinario, F. 2009. Fascismo e antisemitismo. Progetto razziale e ideologia totalitaria. Rome: Laterza.

Gillette, A. 2001. 'The Origins of the "Manifesto of Racial Scientists". Journal of Modern Italian Studies 6 (3): 305-323. 
Guasco, A. 2013. Cattolici e fascisti. La Santa Sede e la politica italiana all'alba del regime (1919-1925). Bologna: Il Mulino.

Israel, G. and P. Nastasi. 1998. Scienza e razza nell'italia fascista. Bologna: Il Mulino.

Kertzer, D. 2001. The Popes Against the Jews: The Vatican's Role in the Rise of Modern Antisemitism. New York: Knopf.

Kertzer, D. 2014. The Pope and Mussolini. The Secret History of Pius XI and the Rise of Fascism in Europe. New York: Random House.

Lebovitch Dahl, J. D. 2003. 'The Role of the Roman Catholic Church in the Formation of Modern Antisemitism: La Civiltà Cattolica, 1850-1879'. Modern Judaism 23 (2): 180-197.

Levis Sullam, S. 2011. 'Per una storia dell'antisemitismo cattolico in Italia'. In Cristiani d'Italia. Chiese, società, Stato (1861-2011), edited by A. Melloni, 461-470. Rome: Istituto della Enciclopedia Italiana Treccani.

Lolli, M. 1938. Ebrei, Chiesa e Fascismo. Tivoli: Mantero.

Maiocchi, R. 1999. Scienza italiana e razzismo fascista. Firenze: La Nuova Italia Editrice.

Matard-Bonucci, M. = A. 2008. L'Italie fasciste et la persécution des Juifs. Paris: Perrin.

Mazzini, E. 2010. 'The Presences of Anti-Semitism in the Catholic World. The Case of the Enciclopedia Cattolica (1948-1954)'. Quest. Issues in Contemporary History 1.

Mazzini, E. 2013. Ostilità convergenti. Stampa diocesana, razzismo e antisemitismo nell'Italia fascista (1937-1939). Naples: Edizioni scientifiche italiane.

Menozzi, D. 2014. 'Giudaica perfidia'. Uno stereotipo antisemita fra liturgia e storia, Bologna: Il Mulino.

Messineo, A. 1939. 'Alla ricerca di una soluzione. Chiarimenti e distinzioni' . La Civiltà Cattolica 1, January: 203-211.

Miccoli, G. 1988. 'Santa Sede e chiesa italiana di fronte alle leggi antiebraiche del 1938'. Studi storici 29: 821-902.

Miccoli, G. 2000. I dilemmi e i silenzi di Pio XII. Milan: Rizzoli.

Miccoli, G, 2003. 'Antiebraismo, antisemitismo: un nesso fluttuante'. In Les racines chrétiennes de l'antisémitisme politique, edited by C. Brice and G. Miccoli, 3-23. Rome: Ecole française de Rome.

Moro, R. 2002. La Chiesa e lo sterminio degli ebrei. Bologna: Il Mulino.

Moro, R. 2003. 'Propagandisti cattolici del razzismo antisemita in Italia'. In Les racines chrétiennes de l'antisémitisme politique, edited by C. Brice and G. Miccoli, 275-345. Rome: Ecole française de Rome.

Moro, R. 2004. 'Nazione, cattolicesimo e regime fascista'. Rivista di storia del cristianesimo 1: 129-147.

Orano, P. 1898. Il problema del cristianesimo, Rome: ed. Bernardo Lux.

Orano, P. 1937. Gli ebrei in Italia, Rome: Pinciana.

Perin, R. 2013. 'Pio XI e la mancata lettera sugli ebrei a Mussolini (agosto 1938)'. Rivista di storia del cristianesimo, 1: 181-206.

Pichetto, M. T. 1983. Alle radici dell'odio. Preziosi e Benigni antisemiti. Milan: Franco Angeli.

Pischedda, B. 2015. L'idioma molesto. Cecchi e la letteratura novecentesca a sfondo razziale. Turin: Nino Aragno Editore.

Pollard, J. 2007. 'Clerical Fascism: Context, Overview and Conclusion'. Totalitarian Movements and Political Religions 8 (2): 433-446.

Porfiri, F. 1940. 'San Tommaso e gli ebrei'. La Difesa della Razza 14: 35-39.

Poulat, E. 1977. Catholicisme, démocratie et socialisme. Le mouvement catholique et Mgr. Benigni de la naissance du socialisme à la victoire du fascisme, Paris : Casterman.

Preziosi, G. 1938. 'Fatti e commenti. Il giudaismo definito da "La Civiltà Cattolica". La Vita italiana, May: 657.

Raspanti, M. 1994. 'I razzismi del fascismo'. In La menzogna della razza, Documenti e immagini del razzismo e dell'antisemitismo fascista, Centro Furio Jesi. Bologna: Grafis.

Rigano, G. 2008. 'Note sull'antisemitismo in Italia prima del 1938'. Storiografia 12: 215-267.

Sarfatti, M. 1994. Mussolini contro gli ebrei. Cronaca dell'elaborazione delle leggi del 1938. Turin: Silvio Zamorani editore. 
Sarfatti, M. 2000. Gli ebrei nell'Italia fascista. Vicende, identità, persecuzione. Turin: Einaudi.

Sassoli de Bianchi, F. 1924. 'Il pericolo giudaico. L'imperialismo d'Israele'. Fede e Ragione, 10 October.

Servi, S. 2005. 'Building a Racial State: Images of the Jews in the Illustrated Fascist Magazine, La Difesa della Razza, 1938-1943'. In Jews in Italy under Fascist and Nazi Rule, 1922-1945, edited by J. Zimmerman, 114-157. Cambridge, UK: Cambridge University Press.

Taradel, R. and B. Raggi. 2000. La segregazione amichevole. La Civiltà Cattolica e la questione ebraica 1850-1945. Rome: Editori riuniti.

Tokarska-Bakir, J. 2015. Légendes du sang. Pour une anthropologie de l'antisémitisme chrétien, 1600-2005. Paris: Albin Michel.

Toscano, M. 1996. 'Marcello Ricci: Una testimonianza sulle origini del razzismo fascista'. Storia contemporanea 27 (5): 879-897.

Toscano, M. 2003. Ebraismo e antisemitismo in Italia. Dal 1848 alla guerra dei sei giorni. Milan: Franco Angeli.

Valbousquet, N. 2017a. 'Antisemitismo italiano e cattolici integralisti nel primo dopoguerra'. Passato $e$ presente 102: 68-91.

Valbousquet, N. 2017b. 'Latinité et antisémitisme latin au service du fascisme: Culture et propagande chez Paolo Orano et Camille Mallarmé, entre France et Italie'. Cahiers de la Méditerranée 95: 191-208.

Valbousquet, N. 2019. Catholique et antisémite: le réseau transnational de Mgr Benigni (1918-1934). Paris: CNRS éditions.

Wolf, H. 2010. Pope and Devil: the Vatican's Archives and the Third Reich. Cambridge, MA: Harvard University Press.

Yerushalmi, Y. 1982. Assimilation and Racial Antisemitism. The Iberian and the German Models. Leo Baeck Memorial Lecture, 26. New York.

Zuccotti, S. 2000. Under his Very Windows: the Vatican and the Holocaust in Italy. New Haven: Yale University Press.

\section{Italian summary}

Questo saggio dimostra che malgrado la condanna da parte del Vaticano del razzismo nazista come ideologia anticristiana, alcuni ambienti cattolici nell'Italia fascista non erano impermeabili a pregiudizi antisemiti e razziali. Prendendo in esame i dibattiti sulla razza e sull'antisemitismo nella propaganda del clerico-fascismo e i suoi echi simultanei nei discorsi della Chiesa, questa ricerca individua la formazione di una specifica corrente cattolica di antisemitismo razziale che escludeva gli ebrei da una definizione religiosamente e etnicamente omogenea della nazione italiana. Una parte significativa dei propagandisti clerico-fascisti tentarono di promuovere un discorso razziale e antisemita in grado di attenersi ai principi tanto del razzismo fascista quanto della cultura cattolica italiana. Questo articolo investiga l'appropriazione cattolica dell'antisemitismo razziale presente in un ampio spettro di posizioni, dai cattolici che dialogarono con la retorica razzista fino a quelli che negarono il valore trasformativo della conversione a causa di presunte barriere razziali. Gli esempi presi in considerazione in questo saggio rimettono in discussione la distinzione tradizionale tra l'antigiudaismo cristiano e l'antisemitismo moderno dimostrando inoltre l'influenza del nesso tra argomenti religiosi e razziali nella definizione di una 'razza ebraica' considerata del tutto estranea all'italianità celebrata dal regime. 